\title{
Determinants of Private Saving in Ethiopia: Johansen Co-Integration Approach
}

\author{
Tizita Gebeyehu \\ Debre Brehan University, College of Business and Economics, Department of Economics
}

\begin{abstract}
Saving has its own effect on economic growth and thus needs a more vigorous work being done about. In addition, in the pursuit of studying saving, the core point to be focused will be its determinants. Therefore, the main objective of this research is to empirically examine the main determinants of private saving in Ethiopia for the period ranging from 1971-2015 by using Johansen maximum likelihood co-integration approach. The result shows that level of real per capital income, inflation, urbanization ratio, bank branch and the dummy variable for political instability are significant variables to determine private saving of Ethiopia in the long run. Moreover, level of per capital income, urbanization ratio, bank branch and the dummy variable for political instability have significant positive effect on private saving of Ethiopia. However, inflation rate influencing private saving negatively and significantly. In addition, in the short run only level of per capital income, Urbanization ratio and bank branch at their difference are statistically significant in determining private saving. Gross domestic product per capital income and urbanization ratio have positive effect on private saving whereas Bank branch has negative effect on private saving of Ethiopia in the short run. Since the effects of a change in a given saving determinant are fully utilized both in the long term and short term, measures such as bank branch expansions and improving both the quality and the quantity of export have to be considered by the concerned authorities.

Keywords: Private saving, Ethiopia, Johansen Co-integration, Long run equation and Error Correction Model

DOI: $10.7176 / \mathrm{JESD} / 10-5-03$
\end{abstract}

Publication date:March $31^{\text {st }} 2019$

\section{INTRODUCTION}

Economic growth is the main target of all countries all over the world including both developed and developing countries. Among other things, rise in $\mathrm{GDP}^{1}$ is a good indicator of economic growth; higher GDP implies higher income and thus higher standard of living. One of the important ingredients of GDP is saving. Therefore, most efforts to increase GDP and thus increase economic growth relay on saving (EEA $\left.{ }^{2}, 2016\right)$.

Ethiopia is among the developing countries that needs fast and sustainable investment growth. However, its saving rate was the lowest for the past several decades. The average saving rate was only $7.9 \%$ of the GDP during the past four decades (1970/71 to 2010/11). Splitting the available data among the three regimes of Ethiopia during the study period also shows that the average saving rate was $13.8 \%$ of GDP during the period from $1970 / 71$ to $1973 / 74,7 \%$ from $1974 / 75$ to $1990 / 91$ and $7.3 \%$ from $1991 / 92$ to $2010 / 11$. This classification implies that, though saving rate was relatively good during the Imperial period, it declined to lower per cents during the Derg regime and the current, $\mathrm{EPRDF}^{3}$ government of Ethiopia (Ademe, 2013).

Moreover, available data from World Bank report (2015) shows that the average saving rate of Ethiopia was very low by any standard. For instance, when compared with the average saving rates of Sub-Saharan Africa (SSA) countries between the period 1980/81 and 2010/11, average saving rate in Ethiopia was only $8.6 \%$ of the GDP. However, during the same period, the average for Sub-Saharan Africa countries was $17.2 \%$ of GDP. This implies how much the saving rates of Ethiopia were too much low even by SSA standards (Wondamo, 2016).

Private saving is a very important factor in bringing economic development, its working or efficiency is determined by different socio economic and political factors. Moreover, these different factors have different effects on private saving either in the negative or positive sense. Therefore, in order to study the effects of private saving on the performance of an economy, one needs to identify first, the factors that are affecting it. By doing so, the researcher could understand why and how changes in private saving occurred and pose possible remedies to correct prevailing problems of private saving by looking at the current situation of the determinants $\left(\mathrm{MOFED}^{4}, 2015\right)$.

Previous studies in case of Ethiopia i.e. Ayalew (1995) and Hadush (2012) did not use important variables in the saving model, which may have significant effect on private saving. There are a number of determinants of private saving which are not still well explained. This paper tries to fill this variable gap by incorporating important variables such as Urbanization ratio, bank branch and political instability. Studies on determinants of private saving on others (not Ethiopia) country cases have been carried out during 1990s and early 2000s.

\footnotetext{
GDP implies Gross Domestic Product

2 EEA: Ethiopian Economic Association

${ }^{3}$ EPRDF: Ethiopian People Republic Democratic Federation

${ }^{4}$ MoFED: Ministry of Finance and Economic Development
} 
Furthermore, Ayalew's study on the determinants of private saving in Ethiopia has been carried out before the world 2007 financial crisis. These imply there is the time gap in these areas. Therefore, this paper is also significant by filling the time gap using data's ranging from the year 1971-2015. As a result, the study is motivated by the basic questions raised in the following section to partially fill in the existing literature, time and variable gap by examining the determinants of private saving from the context of Ethiopia. Therefore, the central task of this paper is to analyze factors determining the private saving in Ethiopia for the period between 1971and 2015 with methodology at hand.

The main objective of this study is to identify the major factors that determine private saving in Ethiopian context from 1971 to 2015. In addition to this, the specific objectives of the paper are to:

- Show trends and performance of private saving during the period under consideration.

- Determine the effects of bank branch and political instability on private saving.

- Empirically examine the effects of inflation and urbanization ratio on private saving of Ethiopia.

Based on the determinants of private saving conducted in different parts of the world the researcher can hypothesize that political instability and bank branch will positively and significantly affect private saving. Whereas inflation and urbanization rate will negatively and significantly affect private saving.

The remaining part of the paper is organized as follows: The next section looks into methodological issues. The third section provides discussion of results and the final section deals with brief concluding remarks.

\section{Methodology of the study}

\subsection{Source and type of data}

Secondary data were employed in this study for time series data running from 1971 to 2015 . This is because most of the data's used for this study are available after the year 1970s and issues related to determinants of private saving gained a great interest of researchers and decision makers in both developing and developed countries after the 1970s. The sources of the data were from different domestic and international bureaus and organizations. The domestic sources are a variety of organizations and ministries like National Bank of Ethiopia (NBE), Ministry of Finance and Economic Development (MoFED), Ethiopian Economic Association (EEA) and also the researcher used data's from international sources like the World Bank (WB).

\subsection{Model-Specification}

In developing a saving model, it is difficult to include all the determinants of private saving because of unavailability of all the data required, unquantifiability of some determinants and small observation. Considering this, explanatory variables include: level of real per capital income, terms of trade, interest rate, inflation, urbanization ratio, number of bank branch and political instability measured by dummy variable.

Using the literatures on the determinants of private saving and following the works of previous researchers such as Tochukwu and Fetu (2007), Said Hallaq (2003), Ayalew (1995) and Hadush (2012) the model employed in this study is expressed in the following manner:

$$
Y_{t}=\alpha+\beta X_{t}+\varepsilon_{t}--(1)
$$

Where $Y_{t}$ - is private saving (PS) at period t.

$$
\begin{aligned}
& X_{t} \text { - is a vector of explanatory variables included in the model at period t. } \\
& \varepsilon_{t} \text { - is the error terms at period t. }
\end{aligned}
$$

More specifically, the following model is fitted to analyze the impacts of explanatory variables on private saving.

$\mathrm{LnPS}_{\mathrm{t}}=\beta_{0}+\beta_{1} \mathrm{LnRGDPPC}_{\mathrm{t}}+\beta_{2} \mathrm{LnTOT}_{\mathrm{t}}+\beta_{3} \mathrm{LnIR}_{\mathrm{t}}+\beta_{4} \mathrm{LNCPI}_{\mathrm{t}}+\beta_{5} \operatorname{LnUR}_{\mathrm{t}}+\beta_{6} \mathrm{LnBB}_{\mathrm{t}}+\beta_{7} \mathrm{D}_{\mathrm{t}}+$ $\varepsilon_{\mathrm{t}}--$ - (2)

Where; $\beta_{0}$ is an intercept term and $\beta_{1}, \beta_{2}, \beta_{3}, \beta_{4}, \beta_{5}, \beta_{6}$ and $\beta_{7}$ are the long run coefficients

LnPS $=$ Natural logarithm of Private savings at period t

LnGDPPC $_{t}=$ Natural logarithm of level of real per capital income at period $\mathrm{t}(+)$

$\mathrm{LnTOT}_{\mathrm{t}}=$ Natural logarithm of Terms of Trade at period $\mathrm{t}(-$ or +$)$;

$\mathrm{LnIR}_{\mathrm{t}}=$ Natural logarithm of interest rate at period $\mathrm{t}(+)$

$\mathrm{LnCPI}_{\mathrm{t}}=$ Natural logarithm of consumer price index (-) at period $\mathrm{t}$ (proxy for inflation), measured as a proxy of macroeconomic uncertainty,

$\mathrm{LnUR}_{\mathrm{t}}=$ Natural logarithm of Urbanization ratio at period $\mathrm{t}(-$ or +$)$

$\mathrm{LnBB}_{\mathrm{t}}=$ Natural logarithm of Bank branch at period $\mathrm{t}(+)$

Dummy $=$ is the dummy variable taken for political instability. Setting 1 for the stable period and 0 otherwise.

$\varepsilon_{\mathrm{t}}=$ Stochastic error term 
In addition, all variables are expressed in log form and hence log linear form of the model is used for private saving model as opposed to linear model. As Gebeyehu (2010) pointed out that results obtained from linear form of the model are not significant and consistent; thus, in order to control the size of data and obtain consistent and reliable estimates log linear model is superior to linear model. Additionally, as Fredric (2003) suggests that log linear model produces better results than linear form of the model.

\subsection{Variable Description}

Level of real per Capital Income (RGDPPC): An increase in GDPPC has a positive effect on private saving. This is due to the fact that an increase in GDPPC means an increase in income. RGDPPC is measured by RGDP/ total population.

Terms of trade: Equals PX/PM, where PX and PM are the price index of exports and imports price index respectively (both in domestic currency).

Interest rate: implies that when there is deposit money at the bank, the bank may earn interest on that money especially in savings accounts or certificates of deposit. The interest rate is generally quoted as annual percentage yield.

Inflation: A fourth issue relates to the role of inflation in determining saving. Inflation is defined as a sustained increase in the general level of prices for goods and services (Aberu, 2010).

Urbanization ratio: Urbanization ratio is compiled under the heading of demographic variables. In their seminal article Ando and Modigliani (1963), show that demographic variables negatively affect savings rates. Urbanization ratio, defined as the percentage of the total population living in urban areas.

Bank Branch: Bank branch is measured by number of banks available for users. Researchers like Athukorala and Sen (2004), Johnson (2011) also used number of banks to measure bank branches to conduct investigation. As number of bank branch increase all the society will have accesses for banking services, one of which is saving.

Political instability: The variables that capture the effects of uncertainty about the future bear on saving rates primarily via their impact on precautionary savings. Political instability, which creates an uncertain economic environment for agents, would be expected to act positively on savings. (Asmelash 2009) also used 1 for political stability for period 1991 up to date and zero for instability for period $1971-1991$ to conduct his study. TABLE 3: VARIABLES DEFINITION, MEASUREMENT, SOURCES AND EXPECTED SIGN

\begin{tabular}{|l|l|l|l|l|}
\hline Variables & \multicolumn{1}{|c|}{ Definition } & Unit & Source & Expected Sign \\
\hline PS & Private saving & In millions of birr & EEA & \\
\hline RGDPPC & Level of real Per capital income & In millions of birr & MOFED & Positive \\
\hline TOT & $\begin{array}{l}\text { Terms of trade (total export price index as } \\
\text { percentage of total imports price index) }\end{array}$ & Index & WB & $\begin{array}{l}\text { either negative or } \\
\text { positive }\end{array}$ \\
\hline CPI & Consumer price index & Index & WB & Negative \\
\hline SIR & Interest rate & Percentage & NBE & Positive \\
\hline UR & Urbanization ratio & Percentage & WB & $\begin{array}{l}\text { either negative or } \\
\text { positive }\end{array}$ \\
\hline BB & Bank branch & In number & NBE & Positive \\
\hline
\end{tabular}

\section{Results and Discussion}

\subsection{Results of Unit Root Test}

Testing for the existence of unit roots is of major interest in the study of time series Models and co-integration. In this study, the Augmented Dickey Fuller (ADF) test is employed to test the stationary of the variables and the test result is given in Table 2 .

TABLE 2: RESULT OF TEST OF STATIONARITY (ADF UNIT-ROOT TEST RESULTS)

\begin{tabular}{lccc}
\hline \multicolumn{1}{c}{ Variable } & ADF Test Statistic & Critical Value & Order of Integration \\
\hline LNPS & -3.424343 & -2.938987 & $\mathrm{I}(1)^{* * *}$ \\
LNRGDPPC & -5.197052 & -3.610453 & $\mathrm{I}(1)^{* * * *}$ \\
LNTOT & -4.390098 & -3.610453 & $\mathrm{I}(1)^{* * * *}$ \\
LNSIR & -2.958534 & -2.936942 & $\mathrm{I}(1)^{* *}$ \\
LNCPI & -2.847738 & -2.606857 & $\mathrm{I}(1)^{*}$ \\
LNBB & -5.729183 & -3.605593 & $\mathrm{I}(1)^{* * *}$ \\
LNUR & -2.753151 & -2.607932 & $\mathrm{I}(1)^{*}$ \\
Residual & -6.034188 & -3.632900 & $\mathrm{I}(0)^{* * *}$ \\
\hline
\end{tabular}

$*$,** and *** shows $10 \%, 5 \%$ and $1 \%$ level of significance respectively; the null hypothesis is that there is a unit root.

Source: Eviews version 6 outputs 
The test has shown that all variables are non-stationary in level (and they become stationary at first difference). Thus the researcher can conclude that all variables included in the private saving model are I (1). Hence, it is possible to employ Johansen procedure to test co integration.

The result of the ADF stationary tests for the residuals indicates that the residual is stationary at $1 \%$ level of significance (i.e. I (0)) showing that there is a long run relationship between the explanatory variable and private saving. In other words, the linear combination of the variables of the model is stationary and they are cointegrated.

Johansen co-integration analysis is very sensitive to the number of lags included in the model. The selected lag length is one. This is because both AIC and SC of optimal lag selection suggest an optimal lag of one at $5 \%$ level of significance.

Johansen co integration test result clearly shows that the null hypothesis of no co-integration is rejected by both the $\lambda \max$ and the $\lambda$ trace statistics.

TABLE 3: JOHANSEN CO INTEGRATION TEST RESULT

\begin{tabular}{|l|l|l|l|l|l|l|l|l|}
\hline $\begin{array}{l}\text { Hypothesized } \\
\begin{array}{l}\text { No. of co- } \\
\text { integration } \\
\text { eqn(s) }\end{array}\end{array}$ & $\begin{array}{l}\text { Trace } \\
\text { statistic }\end{array}$ & $\begin{array}{l}0.05 \\
\text { critical } \\
\text { value }\end{array}$ & $\begin{array}{l}0.01 \text { critical } \\
\text { value }\end{array}$ & P-value & $\begin{array}{l}\text { Max } \\
\text { Eigen } \\
\text { statistic }\end{array}$ & $\begin{array}{l}0.05 \\
\text { critical } \\
\text { value }\end{array}$ & $\begin{array}{l}0.001 \\
\text { critical } \\
\text { value }\end{array}$ & p-value \\
\hline None & 215.12 & $159.53^{* * *}$ & $171.10^{* * *}$ & 0.0000 & 69.16 & $52.36 * * *$ & $58.67 * *$ & 0.0005 \\
At most 1 & 145.96 & $125.62^{* * *}$ & $135.97 * * *$ & 0.0016 & 43.33 & 46.23 & 52.31 & 0.0992 \\
At most 2 & 102.63 & 95.75 & 104.96 & 0.0155 & 33.56 & 40.10 & 45.87 & 0.2254 \\
At most 3 & 69.10 & 69.82 & 77.82 & 0.0573 & 21.44 & 33.88 & 39.37 & 0.6508 \\
At most 4 & 47.63 & 47.86 & 54.68 & 0.0525 & 18.31 & 27.58 & 32.72 & 0.4697 \\
At most 5 & 29.32 & 29.80 & 35.48 & 0.0567 & 16.43 & 21.13 & 25.86 & 0.2008 \\
At most 6 & 12.90 & 15.50 & 19.94 & 0.1188 & 12.86 & 14.26 & 18.52 & 0.0822 \\
At most 7 & 0.03 & 3.84 & 6.63 & 0.1600 & 0.87 & 3.84 & 6.63 & 0.8665 \\
\hline
\end{tabular}

$* *$ and *** shows rejection of null hypothesis at $5 \%$ and $1 \%$ level of significance respectively

Source: Eviews version 6 outputs

Table 3 clearly shows that the null hypothesis of no co-integration is rejected by both the $\lambda \max$ and the $\lambda$ trace statistics. While the trace statistics shows two co-integration equations at $1 \%$ level of significance, maximum Eigen value statistics shows 1 co-integration equations at $1 \%$ level of significance. According to Harris (1995) in Johansen approach to co-integration trace statistics rejects null hypothesis whenever it is true because of small sample size of the data. Thus, the rejection of one co-integration approach by trace statistics may be due to small sample size. Hence, taking the major objective of investigating the determinants of private saving into consideration, the researcher use only one co integrating vector that relates private saving which is the dependent variable to its determinants.

After establishing the existence of one co-integrating relationship between the variables in the private saving model, the next step is to test for the existence of weak exogeneity. The test for zero restrictions on adjustment coefficient is referred to as the test for exogeneity. The results, using the likelihood ratio (LR) test confirm that dependent variable rejects weak exogeneity at $1 \%$ level of significance.

\subsection{The long run equation}

Finally, the structural long run relationship derived from the co-integrating vector normalized with respect to LNPS can be represented as:

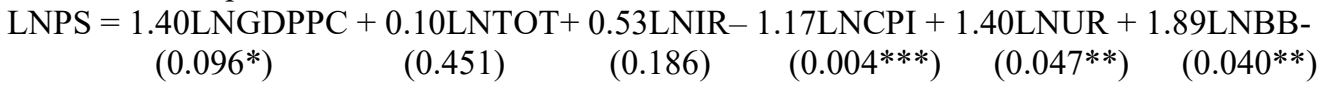
$\left(0.096^{*}\right)$
$(0.451)$
$(0.186)$
$(0.004 * * *)$
$(0.047 * *)$
$\left(0.040^{* *}\right)$

1.10DUMMY

$\left(0.011^{* *}\right)$

Having identified the co integrating vector using Johansen, the next step is to proceed investigates the long run dynamics of the saving process.

The long run relationship between private saving and level of per capital income has a positive coefficient and statistically significant. Thus the Ethiopian experience provides support for the argument that, private saving highly responds to changes in RGDPPC. Out of $1 \%$ increase in level of per capital income, 1.40 percentage points being saved. In this respect, the result of this paper is consistent with the results for Ethiopia of Hadush (2012), Jordan of Said (2003), Turkey of Metin (2000) and Nigeria of Tochukwu and Fastus (2007).

The other variable that determines the long run saving behavior is urbanization ratio. Urbanization ratio is the demographic variable used in this study which has positive and statistically significant influence on private saving. A $1 \%$ increase in urbanization ratio increases private saving by $1.40 \%$ over the long run period. The sign of urbanization ratio is unexpected. The expected sign was negative. This evidence is in line with that of Prema (2003) on the determinants of private saving in India. 
The result revealed that Bank branch is an important determinant of private saving shows positive and statistically significant effect in the long run model which is the same to the researchers' expectation. As bank branch increase by $1 \%$ private saving will increase by $1.89 \%$ which proves that the expansion of bank branches will result in reducing the cost of banking transactions and thus motivate private sector to save. This result is similar to the result of Athukorala and Sen (2004) of India.

The dummy variable to capture political instability shows that positive and significant coefficient. Individuals increase precautionary saving in the face of increased uncertainty in the economic environment. The result supports the result found in Turkey by Metin (2000) and also consistent with the precautionary motive which suggesting that increased political uncertainty induces people to save a larger proportion of their incomes.

Inflation proxies by CPI which is taken as a proxy for macroeconomic uncertainty has a strong negative effect on the private savings. An increase of $1 \%$ in inflation decrease private Saving by $1.17 \%$ over the long run period holding others constant. The result is consistent with the result found by Ayalew (1995) in Ethiopia and Athukorala and Sen (2004) of India.

However, Terms of trade (LNTOT) and Interest rate (LNIR) have positive and insignificant impact on private saving.

\subsection{Vector error correction model (short run equation)}

After determining the long run model and its coefficients, the next step is the determination of short run dynamics. The coefficient of difference represents the coefficients of short run dynamics whereas the coefficient of lagged error correction term ECM (-1) captures the speed of adjustment towards the long run equilibrium relationship. The short run model is obtained via the general to specific model selection method where insignificant coefficients and significant coefficients with unexpected sign are eliminated from the short run model until parsimonious model is obtained. Parsimonious model maximizes the goodness of fit of the model with minimum number of explanatory variables and the reduction process is mostly guided by statistical considerations. Using this specification the parsimonious short run equation is obtained as indicated in table 4.

Table 4 indicates that only Level of per capital income, urbanization rate and Bank branch at their difference are statistically significant in determining private saving in the short run at $1 \%, 10 \%$ and $1 \%$ level of significance respectively. However, as the F-statistics indicated, the short run equation model is jointly significant at $1 \%$ critical value. In addition the value of Durbin Watson test which is around two shows that the model doesn't suffer from the problem of autocorrelation.

The result shows that the coefficient of the error-term (or the Speed of adjustment term) for the estimated private saving equation is statistically significant and negative as expected. Thus, it will rightly act to correct any deviations from long-run equilibrium. Specifically, if actual equilibrium value is too high, the error correction term will reduce it while if it is too low, the error correction term will raise it. In other words it shows the convergence of the model toward the long run equilibrium in case of any disturbance occurs in the short run. The Coefficient -0.151013 shows that 15.10 percentage points' adjustments takes place each year towards long run equilibrium.

TABLE 4: THE RESULT OF SHORT RUN MODEL

\begin{tabular}{|c|c|c|c|c|}
\hline Variable & Coefficient & Std. error & \begin{tabular}{|l|} 
t- statistic \\
\end{tabular} & Prob. \\
\hline DLNPS(-1) & -0.622807 & 0.262136 & -2.375895 & $0.0235 * *$ \\
\hline DLNRGDPPC(-1) & 1.353512 & 0.245654 & 5.509829 & $0.0000 * * *$ \\
\hline DLNUR(-1) & 5.768000 & 3.287088 & 1.754745 & $0.0886 *$ \\
\hline DLNBB(-1) & -2.656391 & 0.610239 & -4.353034 & $0.0001 * * *$ \\
\hline DDUMMY(-1) & 0.204002 & 0.164818 & 1.237741 & 0.2245 \\
\hline $\mathbf{C}$ & 0.182390 & 0.061803 & 2.951156 & $0.0058 * * *$ \\
\hline ECM(-1) & -0.151013 & 0.058386 & -2.586447 & $0.0143 * *$ \\
\hline R-squared & 0.941570 & \multirow{6}{*}{\multicolumn{2}{|c|}{$\begin{array}{l}\text { Mean dependent variable } \\
\text { S.D dependent variable } \\
\text { Akaike information criterion } \\
\text { Schwarz criterion } \\
\text { F-statistic } \\
\text { Prob (F- statistic) }\end{array}$}} & 0.036250 \\
\hline Adjusted R-squared & 0.930947 & & & 0.564849 \\
\hline S. E of regression & 0.148431 & & & -0.819767 \\
\hline Sum squared resid & 0.727047 & & & -0.524213 \\
\hline Log likelihood & 23.39534 & & & 88.63049 \\
\hline Durbin - Watson test & 2.035176 & & & $0.000000 * * *$ \\
\hline
\end{tabular}

Source: Eviews version 6 output Note: $* * *, * *$ and $*$ shows significance level at $\%, 5 \%$ and $10 \%$ level respectively

As in the long run result GDPPC has also positive impact on private saving in the short run implying that improvement in per capital income of the country boosts up private saving. A $1 \%$ increase in GDPPC will increase private saving of Ethiopia by $1.4 \%$ in the short run. 
Urbanization rate has a positive and statistically significant coefficient in the short run. A $1 \%$ increase in urbanization rate increases private saving by $5.8 \%$. The result of LNUR is similar both in the long run and short run equations.

In the short run Bank branch shows negative and statistically significant effect on private saving. As bank branch increase by $1 \%$ private saving will decrease by $2.7 \%$. The short run result of BB contradicts with the view that the expansion of banking facilities since the 1970 s seems to have contributed significantly to improvements in saving propensity in the economy of Ethiopia. This result supports the result found by Athukorala and Sen (2004) in India. According to them the short run result may be due to the reason that even though the expansion of bank branch in Ethiopia increases, it is not proportional to population increase (Bank density is high).

The model passed all the diagnostic tests. The model and parameters of the model are stable as the stability test reported.

\section{Conclusion and policy implications}

The study analyzed the determinants of private saving in the process of Economic development, in light of the Ethiopian experience during the period 1971 - 2015. In this study, the researcher found various determinants of private savings in Ethiopia and has established their relationship in the long run as well as in the short run.

In the long run, the study concludes that level of real per capital income, terms of trade, interest rate, urbanization ratio, bank branch and the dummy variable for political instability are positively affecting private Savings. On the other hand the influence of inflation on private saving is negative. The results are statistically significant for all variables except for Terms of trade and interest rate.

In the short run only level of per capital income, urbanization ratio and bank branch at their difference are statistically significant in determining private saving. However, as the F-statistics indicated, the short run equation model is jointly significant at $1 \%$ critical value. The result shows that the coefficient of the error-term (or the Speed of adjustment term) for the estimated private saving equation is statistically significant and negative as expected.

The empirical findings presented in this study indicate a number of variables that affect private savings in Ethiopia. The complexity of the relationship between saving and other variables is examined. These variables clearly indicate the role of policies Pursued by the country that affect saving. According to this paper empirical finding, the researcher can say that financial market development, macroeconomic condition, political situation and demographic structure may be the core policy instruments in Ethiopia for the saving behavior.

The present study tried to meet gap between the existing literatures by examining the determinant of private saving from the context of Ethiopia but it also has its own limitations and those limitations can be addressed by researchers in future. Accordingly the present study is limited to macroeconomic variables, demographic variables and political variables when examining determinants of private saving. However, there are other factors which may have an impact on private saving as well and not considered in this study due to limited number of available data. These factors may be factors like, Social factors, household head educational level, marital status and access to credit. Hence these factors may help the future researcher's to change their attention to study determinants of saving in the household level (helps to fully understand the behavior of saving in Ethiopia). Thus, future researchers can extend their investigation by taking these factors in to account.

Based on the result found from the descriptive and econometric analysis, the following policy implications are forwarded as alternatives to enhance the performance of the private sector and of course to increase its level, having in mind the contributions it makes to the development of the economy.

Core efforts may be taken to formulate GDP per capital income promotion policies which will encourage the capacity of private saving activities. Ethiopia is characterized by low level of GDP per capital and consequently low level of saving. Thus, the target should be to improve economic activity and accelerate per capital GDP through creating conducive investment to the private sector and put the economy on the sustainable path of growth and financing.

Improving only GDP is not enough for the country like Ethiopia controlling birth is also vital to achieve high level of real per capital income.

The Ethiopian economy is characterized by poor performances of exports which are highly dominated by primary products whose prices remain unstable in international market. So the target in this regard should be to promote the export of industrial products and reduce excessive dependency on the export of primary agricultural products and import of luxury items. This may improves the foreign exchange earning of the country and hence boosts the saving performance.

Create awareness in the reduction of extravagant activities such as wedding and funeral ceremonies. Especially the rural area of Ethiopia is dominated in spending of much money for unnecessary ceremonies. So, creating awareness to develop saving habit among the people is essential in improving the performances of saving. 
Financial sector development is one of the factors affecting private saving. To promote high private saving it is important to encourage people engage in voluntary saving practices through the expansion of bank branch and its facilities. So government may formulate policies to increase number and services of banks to meet the demands of people for saving.

Overall, high unemployment results low disposable income and consequently poor saving performance. In this regard the government should improve the skill, knowledge and training levels of labors through establishing training and skill formation institution that helps for job creation efforts. In addition small scale enterprises should be expanded so that unemployed youths and women participate in income generation activities.

\section{References}

Abu Girma (2004), on the determinants of domestic saving in Ethiopia, paper presented on the second international conference on the Ethiopian economy, EEA, Ethiopia.

Ando A. and Modigliani F. (1963), the life cycle hypothesis of saving, American economic review, 53(1): 15-33

Alemayehu G.( 2005), The Political Economy of Growth in Ethiopia, Chapter 4 of volume 2, Addis Ababa University

Athukorala, Prema-Chandra and Sen Kunal (2004), The Determinants of Private Saving in India, World Development, Vol.32, No.3, pp.491-503.

Ayele Wondamo (2016), Determinants of Private Saving in Ethiopia, unpublished MSc Thesis (Economic policy Analysis), Addis Ababa University.

Bhalla S.S. (1980), Measurement errors and permanent income hypothesis evidence from rural India, American economic review, 63:295-307

Bhandari R., Dahakala D., Pradhan G., and Upedhyaya K. (2007), Determinants of private saving in south Asia, South Asia economic journal, 8:205-17

Bjorn Anderson (1996), on the causality between saving and investment Long-run and short run dynamics and country heterogeneity, Uppsala University, Sweden.

Carroll C.D. (1997), Buffer stock saving and the life cycle / Permanent income hypothesis, the quarterly journal of economics, 112(1):1-55

Carroll C.D. (2006), Consumption and saving: Theory and Evidence, NBER report, research summery

Claudio Pavia and Sarwat Jahan(2003) ,Determinants of private saving in Brazil, Brazilian Journal of Political Economy, vol. 23, no 1 (89)

Costas Meghir(2002), A Retrospective on Friedman's Theory of Permanent Income ,University College London and Institute for Fiscal Studies ,IFS WP04/01

Dayal-Gulati, Anuradha and Christian Thimann (1997). Saving in Southeast Asia and Latin America Compared Searching for Policy Lessons, IMF Working Papers 97/110, International Monetary Fund (Washington, DC).

Daniel Ayalew (1995), Determinants of private domestic saving in Ethiopia, Unpublished MSc thesis, Addis Ababa University, Addis Ababa

Deaton A. (1998), Saving and Liquidity Constraints, Econometrica, 59 (1991): 1221- 1448

Degu Asmelash (2009), Ethiopia fares better in political instability, risk and uncertainty journal, 3: No 24

Duesenberry J. (1949), Income, saving and the theory of consumer behavior, Economica

17(68):451454

Elbadawi Ibrahim A. and Francis M. Mwega (2000), Can Africa's Saving Collapse Be Reversed? , The World Bank Economic Review, 14(3): 415-443

Ernest Aryeetey and Christopher Udry (2000), Center for international development, Harvard University.

Ethiopian Economics Association (2001/20012), annual report on the Ethiopian economy, Addis Ababa, Ethiopia.

Ethiopian Economics Association (2016), annual report on the Ethiopian economy, Addis Ababa, Ethiopia.

Ethiopian Economics Association (1999/2000), Annual Report on the Ethiopian Economy: $2^{\text {nd }}$ edition vol1.1

Fredrick.M.L. (2000), Determinants and Constraints to private saving: The case of Kenya, Kenya

Freidman M. (1957), Theory of consumption function, Princeton university press, ISBN: 0-691-14182-2

Gebrelibanos Hadush (2012), the determinants of private saving in Ethiopia, unpublished MSc. thesis (economic policy analysis), Arba Minch University

Gujarati D. N.( 2004), Basic Econometrics, $4^{\text {th }}$ ed. The McGraw-Hill, Inc., New York.

Haile Ademe (2013), Determinants of domestic saving in Ethiopia: An Autoregressive Distributed Lag (ARDL) bounds testing approach, Journal of economics and international finance, Vol 5(6), pp.248-257

Haile Girma (2013), Effect of foreign Aid on the economic growth of Ethiopia, unpublished MSc Thesis (Economic policy Analysis), Arba Minch University.

Haron Agegnehu (2013), Determinants of domestic saving in Ethiopia, unpublished MSc Thesis (Economic 
policy Analysis), Bahir Dar University.

Hall R.E. (1978), stochastic implication of the life cycle permanent income hypothesis: theory and evidence.

Harris, R. (1995), Using Cointegration Analysis in Econometric Modeling, Prentice Hall, and London.

Harris R. and Sollis R. (2003), Applied Time Series Modeling and Forecasting, Durham University

Houthakker H.S. (1958), the permanent income hypothesis, American economic review, 48(3): 396-404.

Johnson O. (2011), the nexus of private saving and economic growth in an emerging economy: A case of Nigeria, journal of economics and sustainable development, Vol. 2:6

Joseph p. Dejuan and john j. Seater (2004), a simple test of Friedman's permanent income hypothesis, University of Waterloo, Ontario North Carolina State University, 73, 27-46

Keynes, J.M. (1936), the general theory of employment, interest and money, macmillon and Co., Ltd., London

Kivilcim Metein Ozcan, Asli Gunay and, Seda Eratc (2008), Determinants of private savings behavior inTurkey, Bilkent university, Turkey

Loyza N., Lopez H., Schmidt-Hebbel and Serven L. (1999), the world saving database, World Bank, Washington DC.

Loayza Norman, Klaus Schmidt-Hebbel, and Luis Servén (2000) What Drives Private Saving Across the World? The Review of Economics and Statistics, LXXXII, 2, pp. 165-181.

Mahadeva L. and Robinson P. (2004), Unit root testing to help model building, hand book in central banking No.22, bank of England

Mankiew, N.G. (2000), Macroeconomics, 2nd edition, Harvard University

Masson P., Bayoum T., and Samie H. (1995), international evidence on the determinants of private saving, International Monetary Fund, Washington.

Metain Ozcan Kilvicim, (2000), Determinants of private saving in the Arab countries Iran and Turkey Ankar, Turkey.

Mikesell R.F. and J.E. Zinser (1973), the nature of savings function in developing countries: A survey of the theoretical and Empirical Literature, Journal of economic Literature, 11: 1-26

Modigliani F. (1986), Life cycle, individual thrift and the wealth of nations, American economic review, 76:297313.

Modigliani F. and Brumberg R. (1954), Utility analysis and the consumption function, the collected papers of Franco Modigliani, vol.6

MOFED (2015), Macro economic developments in Ethiopia, Addis Abeba, MOFED, annual report

Mogab J. and Bruce Mcclang (2004), a study guide for use with principle of economic, 2nd edition.

Özcan, K. M., A. Gunay, and S. Ertac (2003). Determinants of Private Savings Behavior in Turkey, Applied Economics [Electronic version], 25(12): 1405-1416.

Prema Chandra Athukroala (2003), determinants of private saving in India, Australian national university, Canberra, Australia

Rahim M Quazi, (2003), Effects of political instability on the domestic saving in Bangladesh: An Empirical study, International review of applied economics, vol.17 (1), and pp36-45

Raut L. and Virmani A. (1989), Determinants of consumption and saving behavior in developing countries, the world bank economic review , 3(3): 379-93

Sachs J.D. and F. Larrian B. (1993), Macroeconomics: in the global economy, Harvester, Wheat sheaf

Said Hallaq (2003), determinants of private saving in Jordan, Irbid, Jordan.

Sajid, G.M. (2008), Savings and Economic Growth In Pakistan, an issue of causality, Pakistan Economic and Social Review[Electronic version]46 ( 1), 17- 36

Simeneh Zewdu (2006), Determinants of private investment in Ethiopia, MSc thesis, Addis Abeba University, Addis Ababa, Ethiopia.

Schimdit-Hebbel, K. et'al. (1991), public policies and saving in developing countries, journal of development economics, 36:89-115

Schimdit-Hebbel, K. et'al. (1992), household saving in developing countries: first cross country evidence, World Bank economic review, 6(3): 529-47

Schmidt-Hebbel, K.Serven, L. and Solimano A. (1996), saving and investment: paradigms, puzzles and policies, World Bank.

Tesema Aberu, Tewodros Ayalew and Tewodros Tefera (2010), Determinants of inflation rate in Ethiopia, unpublished MSc thesis (economic policy analysis), Addis Ababa university, Addis Ababa

Tochukwu E.Nwachukwu and Fastus D. Egwaikhide(2007), an error-correction model of the determinants of saving in Nigeria , Ibadad University Journal of Monetary and Economic Integration, Vol. 11, No.2

Verbeek, Marno (2004), A Guide to Modern Econometrics, $4^{\text {th }}$ ed. John Wiley \& Sons Ltd, Erasmus University Rotterdam.

William H.Branson (2003), Macro economic theory and policy , $2^{\text {nd }}$ edition, London

Worku Gebeyehu (2010), Causal links among Saving, investment and Growth and determinants of Saving in 
Sub-Saharan Africa: Evidence from Ethiopia, Ethiopian journal of Economics, volXIX, Num2.

World Bank report (2011), African development indicators, Washington D.C. 20433, U.S.A

World Bank (2015), Ethiopian Economic update, A World Bank Policy Research Report, Oxford University Press.

WWW.investpedia.com/terms/d/dependency ratio. A 